\title{
Synthesis Of Mesoporic Silica From Rice Husk Ash For Pinostrobin Based Drug Delivery
}

\author{
Rifia Wulandari, Saprini Hamdiani ${ }^{\star}$, Nurul Ismillayli \\ Department of Chemistry, Faculty of Mathematics and Natural Science, University of Mataram. Jalan \\ Majapahit No. 62 Mataram 83125 Indonesia. \\ *Email: saprini.h@unram.ac.id
}

Received January 03, 2019; Accepted February 15, 2019

\begin{abstract}
A study has been conducted on the synthesis of mesoporous silica as introductory material pinostrobin anticancer compounds. The aim of this study was to synthesis paramagnetic mesoporous silica from rice husk ash waste; knowing the characteristics of silica gel and mesoporous silica from rice husk ash waste; and to determine the effect of $\mathrm{pH}$, pinostrobin compound concentration, and the contact time on the value of adsorption capacity $(Q)$. Based on the results of the study, it was found that mesoporous silica can be synthesized from the rice husk ash waste. Characterization using FTIR produces silanol $(\mathrm{Si}-\mathrm{OH})$, and siloxan (Si-O-Si). The use of 30\% w/w tartaric acid as a template doesn't change the functional groups of silica.Aadsorption of kinetics followed the pseudo II order kinetic model with a value of $\mathrm{K}=0,03756 \mathrm{~g} \cdot \mathrm{mg}^{-1}$ minute $^{-1}$. Release time of pinostrobin anticancer compounds in vitro occurs in the gastric simulation fluid $(\mathrm{pH} 1.2)$, it was shown that pinostrobin release did not occur for 12 hours. In simulated intestinal fluids ( $\mathrm{pH} 7.4$ ), pinostrobin is released slowly at every hour, then slightly increases at the 10th hour and continues to increase again slowly so that the pinostrobin compound is completely released at 12 hours.
\end{abstract}

Keywords: Mesoporous silica, rice husk ash waste, pinostrobin compound, tartaric acid.

\section{PENDAHULUAN}

Dalam beberapa penelitian menyatakan bahwa kandungan senyawa pinostrobin sebagai senyawa dari tanaman temu kunci mempunyai potensi besar sebagai senyawa anti kanker. Namun penggunaan senyawa pinostrobin secara langsung masih belum efektif karena dapat mengalami degradasi sebelum sampai ke targetnya [1,2]. Salah satu strategi dalam pengantaran obat antikanker yang efektif adalah menggunakan nanopartikel anorganik [3-4]. Material anorganik yang biasa digunakan yaitu alumina, karbon aktif dan zeolit, namun sulit diregenerasi dan masih kurang efektif dalam pemanfaatannya. Adsorben menggunakan bahan baku silika gel merupakan salah satu alternatif paling baik, karena proses pembuatannya yang mudah dan murah [5-10].

Kapasitas adsorpsi silika gel dalam mengadsorpsi senyawa pinostrobin yang berukuran besar dapat ditingkatkan dengan memodifikasi porositasnya dengan penambahan asam tartarat $30 \%$ sebagai pembentuk pori sehingga memperbesar ukuran pori yang diharapkan dapat meningkatkan penyerapan senyawa organik dengan ukuran yang besar sehingga dapat meningkatkan kapasitas adsorpsi.
Pada penelitian ini, silika gel dibuat dari limbah abu sekam padi. Limbah abu sekam padi biasanya tidak dimanfaatkan secara maksimal sehingga dapat menyebabkan pencemaran lingkungan. Senyawa kimia yang paling dominan di dalam limbah abu sekam padi adalah silika yaitu sebesar 72,28 \% [11-13]. Oleh karena itu, pada penelitian ini silika dari limbah abu sekam padi dimanfaatkan dan dimodifikasi silika mesopori untuk digunakan sebagai adsorben

Tujuan penelitian yaitu untuk mensintesis silika gel dari limbah abu sekam padi dengan asam tartarat sebagai pembentuk pori untuk menghasilkan silika mesopori; mengetahui pengaruh $\mathrm{pH}$, konsentrasi, dan waktu kontak (kondisi adsorpsi) senyawa pinostrobin dengan adsorben silika mesopori terhadap nilai kapasitas adsorpsi adsorben; dan mengetahui pelepasan senyawa pinostrobin dengan silika mesopori sebagai material pengantar pada cairan simulasi $\mathrm{pH}$ lambung dan usus.

\section{METODE PENELITIAN}

Alat yang digunakan dalam penelitian ini adalah peralatan analisis dan peralatan penunjang. Untuk peralatan analisis digunakan yaitu 
spektrofotometer UV-Vis, spektrofotometer inframerah (Shimadzu FTIR-8201 PC) ayakan,pengaduk magnet (stirer), oven (Fischer Scienific), timbangan analitik (Shimadzu), tungku pemanas, cawan porseline, alat penggerus (lumping 40 dan mortar), desikator, pompa vakum, kolom EFP.

\section{Bahan-bahan Penelitian}

Bahan-bahan yang digunakan dalam penelitian ini meliputi Sekam padi (diperoleh dari petani di daerah Desa Darek, kecamatan Praya Barat Daya, Kabupaten Lombok Tengah, NTB) sebagai sumber silika, Aquades (Lab kimia dasar FMIPA), asam tartarat (Merck), padatan senyawa pinostrobin, $\mathrm{NaOH} 4 \mathrm{M}, \mathrm{HCl} 3 \mathrm{M}$, $\mathrm{NaOH} 0,1 \mathrm{M}, \mathrm{HCl} 0,1 \mathrm{M}$, larutan buffer $\mathrm{pH}$ lambung $(1,2)$ dan larutan buffer $\mathrm{pH}$ usus $(7,4)$, kertas indikator $\mathrm{pH}$ universal, kertas saring dan kertas saring whattman no. 42.

\section{prosedur Penelitian \\ Preparasi Sampel}

Sekam Padi yang digunakan merupakan sekam padi yang berasal dari Kecamatan Praya Barat Daya, Lombok Tengah, Nusa Tenggara Barat. Sekam padi yang sudah dibersihkan dari campuran lain seperti ranting dan dedaunan dibakar dengan merata hingga terbentuk abu. Abu sekam yang sudah terbentuk kemudian digerus dan diayak dengan ayakan.

\section{Pembuatan natrium silikat $\left(\mathrm{Na}_{2} \mathrm{SiO}_{3}\right)$ dari abu} sekam padi

Pembuatan $\mathrm{Na}_{2} \mathrm{SiO}_{3}$ ini mengacu pada penelitian Hamdiani (2010), sebanyak $20 \mathrm{~g}$ sampel serbuk abu sekam padi ditambahkan dengan $200 \mathrm{~mL} \mathrm{NaOH} 4 \mathrm{M}$, kemudian dididihkan sambil diaduk dengan pengaduk magnet. Setelah mengental dan larutan berwarna hitam, larutan dituangkan ke dalam cawan porselin dan dilebur pada temperatur 500 ${ }^{\circ} \mathrm{C}$ selama 30 menit. Setelah dingin ditambahkan $200 \mathrm{~mL}$ akuades, dibiarkan semalem dan disaring dengan kertas saring Whatman 42. Filtrat yang dihasilkan merupakan larutan natrium silikat $\left(\mathrm{Na}_{2} \mathrm{SiO}_{3}\right)$ yang siap digunakan sebagai bahan pembuatan adsorben silika gel (SG) dan silika mesopori.

\section{Sintesis silika mesopori melalui proses sol- gel}

Sebanyak $20 \mathrm{~mL}$ larutan natrium silikat hasil peleburan abu sekam padi dimasukkan kedalam wadah plastik, ditambahkan $20 \mathrm{~g}$ senyawa asam tartarat. Setelah itu, dilanjutkan dengan menambahkan $\mathrm{HCl} 3 \mathrm{M}$ secara bertetes-tetes dan diaduk dengan pengaduk magnet hingga terbentuk gel sampai $\mathrm{pH}$ larutan netral ( $\mathrm{pH}$ 7). Gel yang terbentuk didiamkan semalam, dicuci dengan akuades hingga netral dan dikeringkan dioven pada suhu $70{ }^{\circ} \mathrm{C}$. Setelah kering digerus dan diayak menggunakan ayakan 200 mesh. Silika Mesopori yang diperoleh dikarakterisasi dengan spektrofotometer FTIR.

\section{Uji Pelepasan Sistem Penghantar Obat Senyawa Pinostrobin Secara In Vitro}

Metode ini dilakukan berdasarkan penelitian Putra dan Mustika (2016), dimana pelepasan obat secara in vitro dilakukan dengan cara merendam sejumlah sampel silika mesopori dengan sejumlah pinostrobin dalam kondisi optimum adsorpsi. Setelah itu campuran tersebut disaring, kemudian residu yang didapatkan di rendam di dalam $100 \mathrm{~mL}$ larutan buffer pada $\mathrm{pH} 1,2$ (cairan lambung simulasi) dan pada $\mathrm{pH} 7,4$ (cairan usus simulasi). Larutan buffer $\mathrm{pH}$ 1,2 dibuat dengan mencampurkan 250 $\mathrm{mL} \mathrm{HCl} 0,2 \mathrm{M}$ dan $147 \mathrm{~mL} \mathrm{KCl} 0,2 \mathrm{M}$, sedangkan larutan buffer $\mathrm{pH} \mathrm{7,4}$ dibuat dengan mencampurkan $250 \mathrm{~mL} \quad \mathrm{KH}_{2} \mathrm{PO}_{4} \quad 0,1 \mathrm{M}$ dan $195,5 \mathrm{~mL} \mathrm{NaOH} 0,1 \mathrm{M}$ (Datta dan Kaur, 2014). Campuran diaduk dengan kecepatan 300 rpm menggunakan pengaduk magnetik pada suhu $37{ }^{\circ} \mathrm{C}$. Setiap interval 1 jam, sebanyak $5 \mathrm{~mL}$ sampel diambil dan digantikan dengan volume buffer yang sama. Sampel yang telah diambil tersebut kemudian disaring, dan diukur konsentrasinya menggunakan spektrofotometer UV-Vis pada panjang gelombang $370 \mathrm{~nm}$. Uji pelepasan senyawa ini dilakukan selama periode 12 jam.

\section{HASIL DAN PEMBAHASAN}

\section{Sintesis Silika Gel dan Silika Mesopori melalui Proses Sol-Gel}

Silika gel dan silika mesopori dapat disintesis melalui proses sol-gel dengan melakukan kondensasi larutan natrium silikat dalam suasana asam. Pada pembuatan silika gel dilakukan dengan menambahkan $\mathrm{HCl} 3 \mathrm{M}$ secara bertetes-tetes sampai $\mathrm{pH}$ netral $(\mathrm{pH}=7)$ atau sampai terbentuk gel. Penambahan asam dimaksudkan untuk mengatur $\mathrm{pH}$ dalam pembentukan gel dalam larutan. Kondisi $\mathrm{pH} 7$ ini, silika gel yang dihasilkan memiliki rendemen dan luas permukaan yang paling besar. Proses pebentukan gel terjadi melalui reaksi pembentukan ikatan siloksan -Si-O-Si- dari silikat [14-15]. Karakterisasi terhadap silika gel dan silika mesopori yang dilakukan pada penelitian ini, yaitu karakterisasi kimia dengan mengidentifikasi gugus-gugus fungsi yang 
terdapat pada silika gel dan silika mesopori menggunakan instrument spektrofotometer FTIR. Hasil karakterisasi menggunakan spektrofotometer FTIR diperlihatkan pada Gambar 1

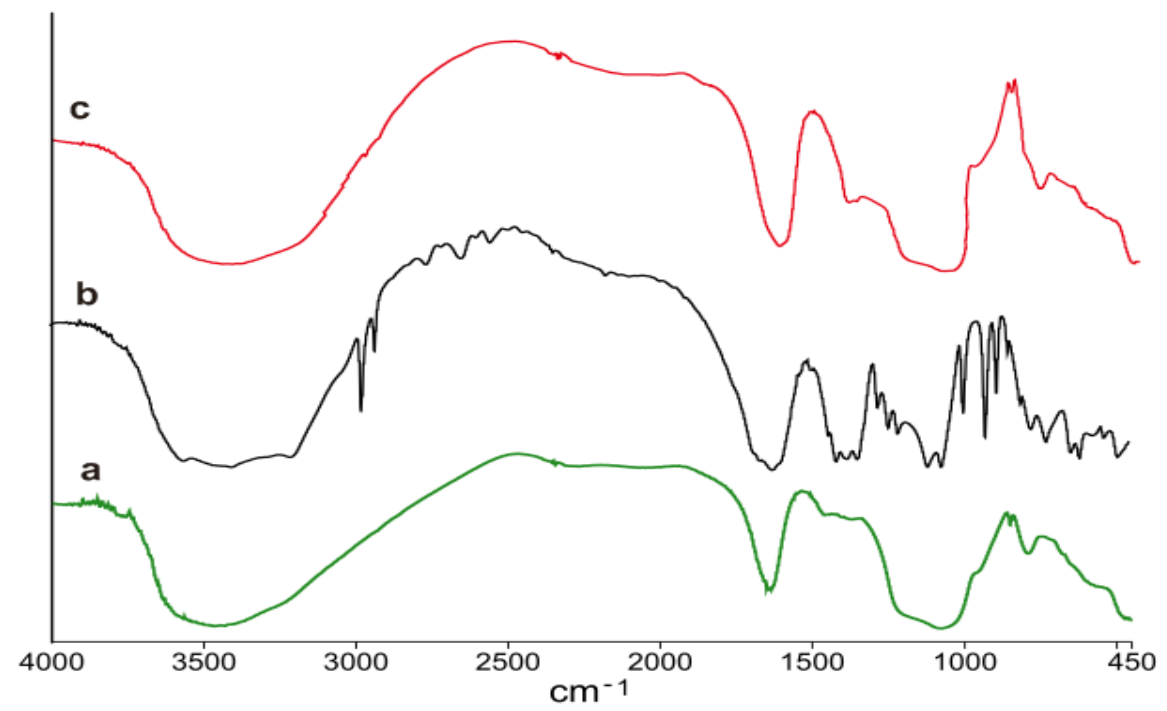

Gambar 1. Spektrum FTIR silika gel (a), silika gel dengan asam tartarat (b), Silika mesopori (c).

Berdasarkan Gambar 1 gugus fungsi pada silika gel diperoleh serapan gugus Si-O yang dominan pada yakni panjang gelombang $1091,84 \mathrm{~cm}^{-1}, 958,36 \mathrm{~cm}^{-1}, 796,07 \mathrm{~cm}^{-1}, 466,86$ $\mathrm{cm}^{-1}$. Tampak adanya vibrasi tekuk dari siloksan pada bilangan gelombang $466,86 \mathrm{~cm}^{-1}$. Vibrasi ulur Si-O dari siloksan ditunjukkan oleh pita serapan pada bilangan gelombang 796,07 $\mathrm{cm}^{-1}$. Vibrasi ulur Si-O silanol ditunjukkan oleh serapan pada bilangan gelombang $958,36 \mathrm{~cm}^{-1}$. Pita serapan yang kuat pada bilangan gelombang $1091,84 \mathrm{~cm}^{-1}$ merupakan vibrasi ulur simetris Si-O dari siloksan (Si-O-Si). Pada bilangan gelombang $1638,41 \mathrm{~cm}^{-1}$ muncul serapan dari vibrasi tekuk $\mathrm{O}-\mathrm{H}$ silanol, dan pada bilangan gelombang $3467,1 \mathrm{~cm}^{-1}$ muncul serapan dari vibrasi ulur $\mathrm{O}-\mathrm{H}$ silanol. Secara umum pita serapan yang muncul pada spektra silika gel menunjukkan bahwa gugus-gugus fungsional yang terdapat pada silika gel hasil pembuatan dari abu sekam padi adalah gugus silanol (Si-OH) dan gugus siloksan (Si-O-Si). Pita serapan dan bilangan gelombang spektrofotometer silika gel (a), silika dengan asam tartarat (b), dan silika mesopori (c) diperlihatkan pada Tabel 1.

Tabel 4.1 Pita serapan dan bilangan gelombang spektrofotometer FTIR Silika Gel (a), Silika dengan template (b), silika mesopori (c).

\begin{tabular}{|c|c|c|c|c|c|c|c|c|}
\hline \multicolumn{3}{|c|}{ Silika Gel } & \multicolumn{3}{|c|}{$\begin{array}{c}\text { Silika Gel dengan Penambahan } \\
\text { Asam Tartarat }\end{array}$} & \multicolumn{3}{|c|}{ Silika Mesopori } \\
\hline $\begin{array}{l}\text { Pita } \\
\text { serapan }\end{array}$ & $\begin{array}{c}\text { Hasil } \\
\text { Penelitian } \\
\left(\mathrm{cm}^{-1}\right)\end{array}$ & $\begin{array}{c}\text { Nuryono } \\
{[14-15]} \\
\left(\mathrm{cm}^{-1}\right)\end{array}$ & $\begin{array}{l}\text { Pita } \\
\text { serapan }\end{array}$ & $\begin{array}{c}\text { Hasil } \\
\text { Penelitian } \\
\left(\mathrm{cm}^{-1}\right)\end{array}$ & $\begin{array}{c}\text { Nuryono } \\
{[14-15]} \\
\left(\mathrm{cm}^{-1}\right)\end{array}$ & $\begin{array}{l}\text { Pita } \\
\text { serapan }\end{array}$ & $\begin{array}{l}\text { Hasil } \\
\text { Penelitian } \\
\left(\mathrm{cm}^{-1}\right)\end{array}$ & $\begin{array}{l}\text { Nuryono } \\
{[14-15]} \\
\left(\mathrm{cm}^{-1}\right)\end{array}$ \\
\hline $\mathrm{O}-\mathrm{H}$ & 3467,1 & 3425,58 & $\mathrm{Si}-\mathrm{OH}$ & 3400,81 & 3409,9 & $\mathrm{Si}-\mathrm{OH}$ & 3467,1 & 3409,9 \\
\hline $\mathrm{O}-\mathrm{H}$ & 1638,41 & 1627,90 & $\mathrm{C}=\mathrm{O}$ & 1735,2 & 1739,7 & $\mathrm{C}=\mathrm{O}$ & - & - \\
\hline $\mathrm{Si}-\mathrm{O}$ & 1091,84 & 1095,57 & $\mathrm{Si}-\mathrm{O}$ & 1083,11 & 1087,8 & $\mathrm{Si}-\mathrm{O}$ & 1055,31 & 1058,8 \\
\hline $\mathrm{Si}-\mathrm{O}$ & 958,36 & 956,69 & $\mathrm{C}-\mathrm{O}$ & 1132,81 & 1134,1 & $\mathrm{C}-\mathrm{O}$ & - & - \\
\hline $\mathrm{Si}-\mathrm{O}$ & 796,07 & 802,39 & $\mathrm{Si}-\mathrm{O}$ & 796,07 & 789,11 & $\mathrm{Si}-\mathrm{O}$ & 691,89 & 798,5 \\
\hline $\mathrm{Si}-\mathrm{O}$ & 466,86 & 470,63 & $\mathrm{Si}-\mathrm{O}$ & 466,86 & 464,8 & $\mathrm{Si}-\mathrm{O}$ & 479,21 & 466,7 \\
\hline
\end{tabular}


Pada silika gel dengan penambahan template asam tartarat, pita tajam pada 3400,81 $\mathrm{cm}^{-1}$ diakibatkan tidak terbentuknya ikatan hidrogen dalam interaksi antara silika gel dengan asam tartarat. Pita kuat dan karakteristik pada $1735,2 \mathrm{~cm}^{-1}$ menunjukkan adanya gugus karbonil $\mathrm{C}=\mathrm{O}$ dari asam tartarat. Penambahan asam tartrat juga menambah intensitas vibrasi ulur asimetris Si-O dari gugus siloksan yaitu $1083,11 \mathrm{~cm}^{-1}$ dibandingkan dengan silika gel. Hal ini kemungkinan disebabkan oleh transfer elektron atom $\mathrm{O}$ dari gugus karboksil maupun gugus silanol, dapat menyerang atom Si dari silika gel membentuk Si-O-Si. Hal ini juga menunjukkan telah terjadi penambahan intensitas gugus silanol dan pembentukan ikatan siloksan (Si-O-Si). Untuk silika mesopori dengan template asam tartrat yang telah dihilangkan dengan metode pencucian dengan menggunakan pelarut air, terjadi pergeseran bilangan gelombang untuk ikatan siloksan (Si-OSi) menjadi $1055,31 \mathrm{~cm}^{-1}$, hal ini menunjukkan energi ikat siloksan menurun, sehingga ikatan antar atom melemah dan mengakibatkan putusnya ikatan Si-O-Si antara permukaan silika mesopori dengan permukaan asam tartarat. Selain itu, serapan karakteristik gugus karbonil $\mathrm{C}=\mathrm{O}$ dari asam tartrat pada $1735,2 \mathrm{~cm}^{-1}$ dan pita-pita tajam pada daerah sekitar $1132,81 \mathrm{~cm}^{-1}$ yang merupakan panjang gelombang untuk ikatan $\mathrm{C}-\mathrm{O}$ sudah tidak muncul lagi, hal ini menunjukkan bahwa template asam tartarat telah berhasil dihilangkan dari silika mesopori.

Penggunaan asam tartarat 30\% dapat menghasilkan diameter pori lebih besar yaitu 48,186 Á. Hal ini disebabkan karena adsorpsi template asam tartarat kedalam struktur silika gel akan mencegah pertumbuhan partikel silikat dan kondensasi silang antar partikel silikat, sehingga terbentuk suatu 'ruang' antar partikel silikat. Asam tartarat yang terdapat dalam ruang tersebut akan keluar, kemudian terbentuk pori dengan ukuran yang lebih besar.

\section{Karakterisasi adsorben setelah proses adsorpsi}

Karakterisasi adsorben setelah adsorpsi dilakukan untuk mengetahui apakah senyawa pinostrobin telah teradsorpsi oleh adsorben silika mesopori atau tidak dengan melihat pergeseran panjang gelombang pada spektrum spektrofotometer FTIR. Spektrum spektrofotometer FTIR silika mesopori sebelum dan setelah adsorpsi diperlihatkan pada Gambar 2.

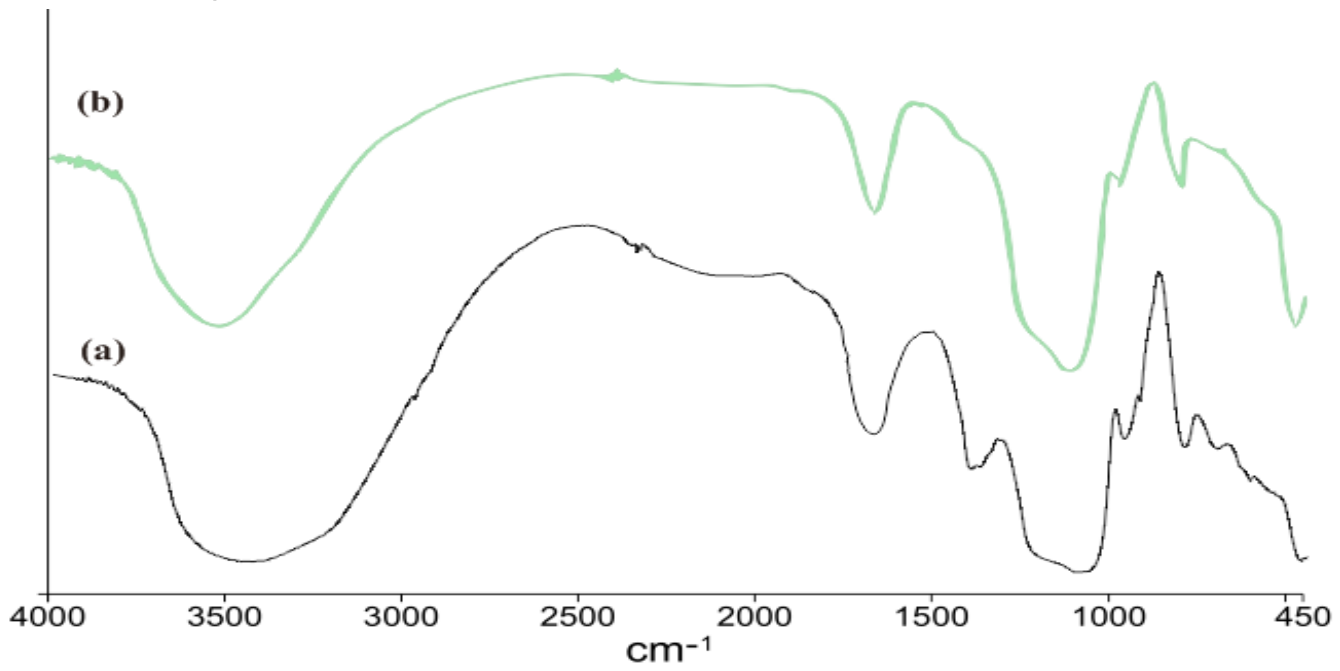

Gambar 2 Spektrum IR silika mesopori sebelum adsorpsi a), silika mesopori setelah adsorpsi b).

Berdasarkan Gambar 2 terlihat perbedaan antara silika mesopori sebelum dan sesudah adsorpsi, yaitu terjadi pergeseran bilangan gelombang pada daerah sekitar 3400 $\mathrm{cm}^{-1}$, dari sebelum adsorpsi pada $3467,1 \mathrm{~cm}^{-1}$. Hal ini dimungkinkan karena terbentuknya ikatan hidrogen antara gugus silanol $(\mathrm{Si}-\mathrm{OH})$ dari silika mesopori dengan $\mathrm{O}$ karbonil senyawa pinostrobin. Pembentukan ikatan hidrogen ini akan melemahkan ikatan $\mathrm{O}-\mathrm{H}$ silanol, energi ikat menurun sehingga terjadi pergeseran bilangan gelombang menjadi lebih kecil. Perbandingan data bilangan gelombang sebelum dan sesudah adsorpsi diperlihatkan pada Tabel 2. 
Tabel 2 Perbandingan data bilangan gelombang FTIR sebelum dan setelah adsorpsi

\begin{tabular}{lllll}
\hline Pita serapan & \multicolumn{2}{c}{ Sebelum adsorpsi } & \multicolumn{3}{c}{ Setelah adsorpsi } \\
\cline { 2 - 5 } & $\begin{array}{c}\text { Bil. Gelombang } \\
\left(\mathrm{cm}^{-1}\right)\end{array}$ & $\begin{array}{l}\text { Transmitan } \\
(\%)\end{array}$ & $\begin{array}{l}\text { Bil. Gelombang } \\
\left(\mathrm{cm}^{-1}\right)\end{array}$ & $\begin{array}{l}\text { Transmitan } \\
(\%)\end{array}$ \\
\hline$-\mathrm{OH}$ & 3467,1 & 0,74 & 3466,5 & 5,7 \\
$-\mathrm{OH}$ & 1619,48 & 1,59 & 1605,71 & 14,6 \\
Si-O & 1055,31 & 0,2 & 1053,8 & 1,79 \\
Si-O & 479,21 & 2,1 & 466 & 5,43 \\
\hline
\end{tabular}

Berdasarkan Gambar 2 dan Tabel 42 terlihat bahwa terjadi pergeseran bilangan gelombang silika mesopori sebelum adsorpsi dan setelah adsorpsi. Pergeseran bilangan gelombang terjadi pada gugus fungsi $\mathrm{Si}-\mathrm{OH}$, dan Si-O yang disertai dengan naiknya persen transmitan setelah proses adsorpsi. Hal tersebut sesuai dengan hukum Lambert-beer yang menyatakan bahwa transmitan berbanding terbalik dengan absorbansi dan konsentrasi. Peningkatan nilai transmitan ini menunjukkan telah terjadi pengurangan intensitas serapan untuk ikatan-ikatan tersebut, intensitas yang menurun tersebut disebabkan ikatan senyawa pinostrobin dengan gugus tersebut telah terjadi. Pergeseran bilangan gelombang setelah adsorpsi menandakan bahwa senyawa pinostrobin telah teradsorpsi oleh adsorben. Terbentuknya ikatan antara adsorben dengan senyawa pinostrobin akan menyebabkan gerak vibrasi pada struktur adsorben menjadi lebih kaku sehingga frekuensi yang dihasilkan menjadi lebih rendah. Nilai frekuensi berbanding terbalik dengan panjang gelombang, dimana semakin tinggi nilai panjang gelombang maka akan menurunkan nilai bilangan gelombang yang dihasilkan sehingga pita serapan yang diperoleh untuk adsorben setelah adsorpsi lebih rendah dibandingkan dengan sebelum proses adsorpsi.

\section{Isoterm adsorpsi}

Keadaan kesetimbangan adsorpsi senyawa pinostrobin dengan menggunakan adsorben silika mesopori dapat dinyatakan secara matematis dengan isoterm adsorpsi (Nuryono dkk, 2014). Ada beberapa model yang dapat digunakan untuk menggambarkan data-data percobaan isoterm adsorpsi, namun pada penelitian ini menggunakan dua model persamaan yaitu persamaan Langmuir dan Freundlich, hal ini karena kedua persamaan ini yang paling sering digunakan pada penelitianpenelitian tentang adsorpsi. Gambar 3 menunjukkan isotherm Freundlich. Kurva model Isoterm Freundlich dibuat dengan membuat grafik hubungan antara log Qe lawan log Ce. Kurva isoterm Freundlich diperlihatkan pada Gambar 3.

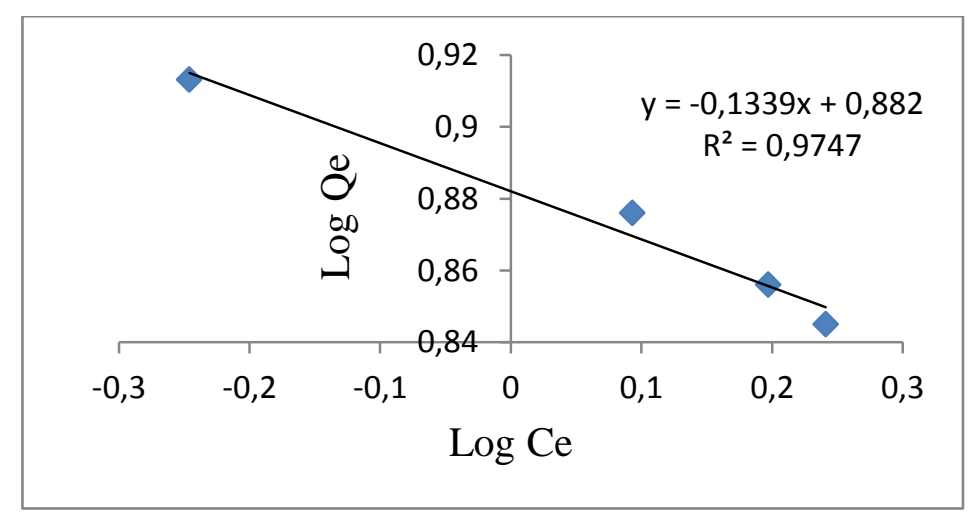

Gambar 3 Kurva isoterm Freundlich 
Model Isoterm Freundlich mengasumsikan bahwa terdapat lebih dari satu lapisan adsorbat (multilayer) dan sisi (permukaan adsorben) bersifat heterogen sesuai dengan kemungkinan variasi permukaan, yaitu adanya perbedaan energi pengikat pada setiap sisi dimana proses di tiap-tiap sisi adsorpsi mengikuti model Isoterm Langmuir Berdasarkan Gambar 3 terlihtat perbandingan nilai $R^{2}$ pada isotherm Freundlich dan isotherm Langmuir. Model isotherm yang sesuai dengan data hasil penelitian diuji dengan analisis regresi linear sederhana yaitu dengan melihat data nilai koefisien korelasinya $\left(R^{2}\right)$. Jika nilai $R^{2}$ semakin mendekati 1 maka dapat dikatakan bahwa terdapat pengaruh yang semakin besar dan keterkaitan antar variabel semakin kuat. Dalam penelitian ini, nilai $R^{2}$ pada isotherm Freundlich lebih mendekati 1 dibandingkan dengan $\mathrm{R}^{2}$ pada isotherm Langmuir. Hal ini menunjukkan bahwa pada penelitian ini digunakan isotherm Freundlich yang artinya, penyerapan senyawa pinostrobin yang terjadi adalah secara fisika). Berdasarkan model isotherm Freundlich mengasumsikan bahwa adsorben memiliki permukaan yang heterogen dan tiap molekul memiliki potensi penjerapan yang berbeda-beda serta asumsi bahwa adsorpsi terjadi multilayer pada permukaan adsorben [16-17].

Tabel 3 Data hasil penentuan model kinetika adsorpsi

\begin{tabular}{lll}
\hline Model kinetika & Parameter & Nilai parameter \\
\hline Orde I & $\mathrm{R}^{2}$ & 0,9485 \\
& $\mathrm{k}\left(\right.$ menit $\left.^{-1}\right)$ & $34,2 \times 10^{-3}$ \\
Orde II & $\mathrm{R}^{2}$ & 0.9297 \\
& $\mathrm{k}\left(\right.$ menit $\left.^{-1}\right)$ & $23,3 \times 10^{-3}$ \\
Pseudo orde I & $\mathrm{R}^{2}$ & 0.9371 \\
& $\mathrm{k}\left(\right.$ menit $\left.^{-1}\right)$ & $55962 \times 10^{-6}$ \\
Pseudo orde II & $\mathrm{R}^{2}$ & 0,9974 \\
& $\mathrm{k}\left(\right.$ g.mg $^{-1}$ menit $\left.^{-1}\right)$ & 0,03756
\end{tabular}

\section{Kinetika adsorpsi}

Berdasarkan Tabel 3 menunjukkan bahwa nilai linearitas paling baik atau nilai $R$ mendekati 1 yaitu model kinetika pseudo orde 2 . Model kinetika pseudo order dua tergantung pada kemampuan mengadsorp masing-masing fase padat. Jika diasumsikan bahwa kapasitas adsorpsi proposional terhadap jumlah situs aktif (active site) pada adsorben. Model kinetika reaksi ini menunjukkan bahwa laju adsorpsi setara dengan kuadrat konsentrasi senyawa pinostrobin yang diekspresikan dengan $\left(q_{e}-q_{t}\right)^{2}$ pada persamaan pseudo orde 2. Semakin tinggi konsentrasi maka memperbesar kemungkinan tumbukan efektif yang akan mempercepat laju reaksi.

\section{Uji pelepasan obat senyawa antikanker pinostrobin}

Grafik pola pelepasan pinostrobin pada cairan simulasi $\mathrm{pH}$ lambung diperlihatkan pada Gambar 4. Berdasarkan Gambar 4 dapat dilihat tidak terjadi pelepasan pinostrobin pada $\mathrm{pH}$ tersebut sampai rentang waktu $12 \mathrm{jam}$. Hal ini mengindikasikan kuatnya interaksi pinostrobin dengan silika mesopori pada $\mathrm{pH}$ ini. Pada $\mathrm{pH}$ asam, situs-situs aktif silika mesopori teprotonasi dan menyebabkan situs-situs aktif tersebut bermuatan positif. Hal ini menyebabkan obat tetap terperangkap dalam kerangka silika. Hasil ini dapat memberikan gambaran, bahwa pinostrobin tidak terabsorpsi di lambung, sehingga kemungkinan pinostrobin untuk mengalami efek lintas pertama menjadi tidak ada. Akibatnya bioavailibilitas pinostrobin didarah bisa menjadi tinggi. Dimana bioavailibilitas suatu senyawa obat tinggi menggambarkan kandungan obat tersebut juga tinggi untuk mencapai tempat aksinya. Apabila terjadi efek lintas pertama maka suatu obat akan mengalami metabolisme sebelum mencapai sirkulasi sistemik, dengan demikian akan mengurangi bioavailibilitasnya (konsentrasi obat berkurang secara besar sebelum mencapai sirkulasi sistemik). Dengan adanya peristiwa ini sering menginaktifkan obat-obatan yang melintasi saluran gastrointestinal menuju ke tubuh. Untuk pola pelepasan pinostrobin pada cairan simulasi $\mathrm{pH}$ usus $(\mathrm{pH} 7,4)$ diperlihatkan pada Gambar 4. 

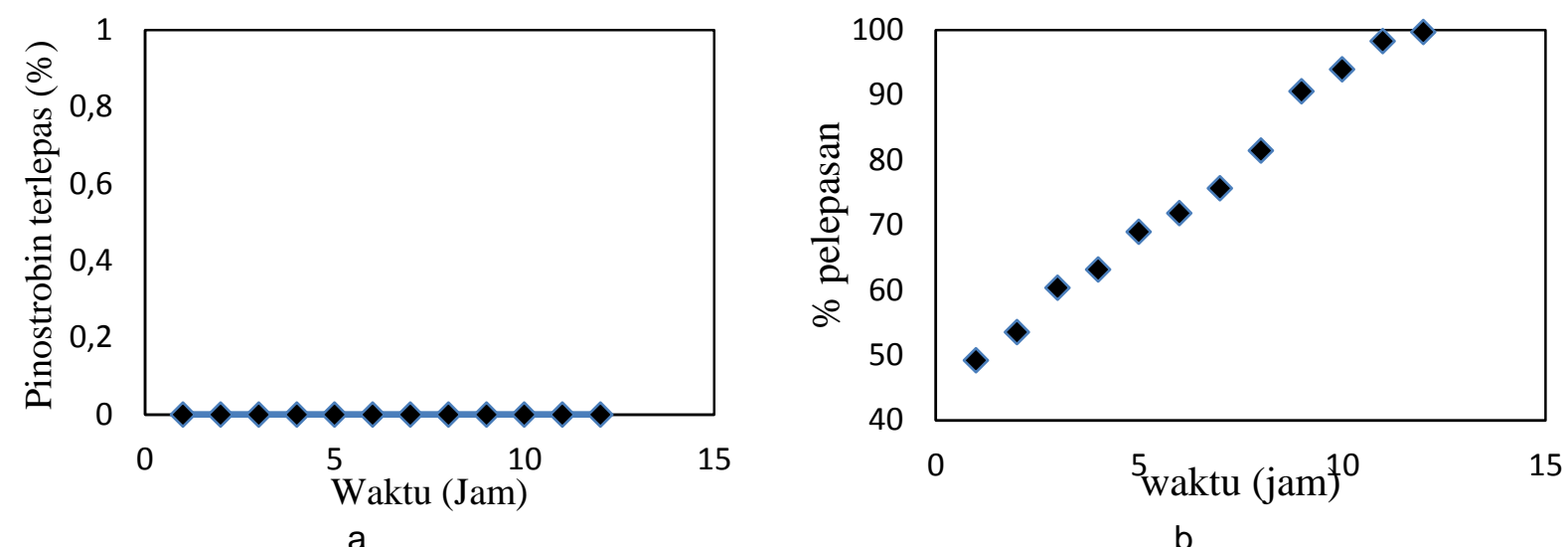

Gambar 4. Pola pelepasan pinostrobin pada cairan a) simulasi lambung $(\mathrm{pH} \mathrm{1,2);} \mathrm{)} \mathrm{simulasi} \mathrm{usus} \mathrm{(} \mathrm{pH}$ $7,4)$.

Berdasarkan Gambar 4 pada cairan simulasi usus $(\mathrm{pH} 7,4)$, pelepasan pinostrobin terjadi secara perlahan-lahan pada setiap jam. Pelepasan pinostrobin terjadi karena total muatan permukaan silika mesopori menjadi netral. Hal ini mengakibatkan tidak terjadinya interaksi atau ikatan antara silika mesopori dan senyawa pinostrobin. Hal ini memaksa pinostrobin terlepas dari matriks silika mesopori. Tren pelepasan senyawa pinostrobin meningkat secara perlahan-lahan sampai terlepas sempurna pada jam ke-12.

\section{KESIMPULAN}

Berdasarkan data dan pembahasan hasil pengujian dalam penelitian ini dapat diambil beberapa kesimpulan sebagai berikut:

(1) Silika gel dan silika mesopori dapat disintesis dari natrium silika hasil peleburan abu sekam padi dengan penambahan template asam tartarat melalui proses sol gel.

(2) $\mathrm{pH}$ optimum adsorpsi senyawa pinostrobin oleh silika mesopori diperoleh pada $\mathrm{pH} 5$, dengan konsentrasi optimum pada $9 \mathrm{ppm}$ dan waktu kontak optimum pada 30 menit, sedangkan untuk konsentrasi senyawa pinostrobin berbanding lurus dengan kapasitas adsorpsi silika mesopori, dengan model isoterm yang cocok adalah model isoterm Freundlich dan kinetika adsorpsi yang diikuti yaitu model kinetika pseudo orde II.

(3) Uji pelepasan senyawa antikanker pinostrobin pada cairan simulasi lambung $(\mathrm{pH}=1,2)$ silika akan terprotonasi yang menyebabkan senyawa pinostrobin tetap terikat pada silika mesopori, sehingga tidak terjadi pelepasan pada rentang waktu 12 jam. Pada cairan simulasi usus
(pH 7,4), silika akan bermuatan netral sehingga tidak terjadi ikatan antara silika mesopori dengan senyawa pinostrobin yang menyebabkan terlepasnya senyawa pinostrobin pada silika mesopori.

\section{DAFTAR PUSTAKA}

[1] Mosaddik, A., Ravinayagam, V., Elaanthikkal, S., Fessi, H., Badri, W., \& Elaissari, A. (2018). Development and Use of Polymeric Nanoparticles for the Encapsulation and Administration of Plant Extracts. In Natural Products as Source of Molecules with Therapeutic Potential (pp. 391-463). Springer, Cham.

[2] Raheem, I. A. A., Razek, A. A., Elgendy, A. A., Saleh, N. M., Shaaban, M. I., \& ElHady, F. K. A. (2019). Design, Evaluation And Antimicrobial Activity Of Egyptian Propolis-Loaded Nanoparticles: Intrinsic Role As A Novel And Naturally Based Root Canal Nanosealer. International journal of nanomedicine, 14, 8379.

[3] Sokolova, V., \& Epple, M. (2008). Inorganic nanoparticles as carriers of nucleic acids into cells. Angewandte chemie international edition, $47(8)$, 1382-1395.

[4] Liu, Y., Miyoshi, H., \& Nakamura, M. (2007). Nanomedicine for drug delivery and imaging: a promising avenue for cancer therapy and diagnosis using targeted functional nanoparticles. International journal of cancer, 120(12), 2527-2537. 
[5] Madieh, S., Simone, M., Wilson, W., Mehra, D., \& Augsburger, L. (2007). Investigation of drug-porous adsorbent interactions in drug mixtures with selected porous adsorbents. Journal of pharmaceutical sciences, 96(4), 851863.

[6] Monkhouse, D. C., \& Lach, J. L. (1972). Use of adsorbents in enhancement of drug dissolution I. Journal of pharmaceutical sciences, 61(9), 14301435.

[7] Ahuja, G., \& Pathak, K. (2009). Porous carriers for controlled/modulated drug delivery. Indian journal of pharmaceutical sciences, 71(6), 599.

[8] Chen, J. F., Ding, H. M., Wang, J. X., \& Shao, L. (2004). Preparation and characterization of porous hollow silica nanoparticles for drug delivery application. Biomaterials, 25(4), 723727.

[9] Miftiyati, S., Hamdiani, S., \& Darmayanti, M. (2018). Synthesis Of Paramagnetic Merkapto Silica Hybrid From Rice Husk Ash For Ag(I) Adsorben. Acta Chimica Asiana, 1(2), 30-36.

[10] Ahola, M., Kortesuo, P., Kangasniemi, I., Kiesvaara, J., \& Yli-Urpo, A. (2000). Silica xerogel carrier material for controlled release of toremifene citrate. International journal of pharmaceutics, 195(1-2), 219-227.

[11] Yalcin, N., \& Sevinc, V. (2001). Studies on silica obtained from rice husk. Ceramics international, 27(2), 219224.

[12] Huang, S., Jing, S., Wang, J., Wang, Z., \& Jin, Y. (2001). Silica white obtained from rice husk in a fluidized bed. Powder Technology, 117(3), 232-238.

[13] Payá, J., Monzó, J., Borrachero, M. V., Mellado, A., \& Ordoñez, L. M. (2001). Determination of amorphous silica in rice husk ash by a rapid analytical method. Cement and Concrete Research, 31(2), 227-231.
[14] Nuryono, N., Rosiati, N. M., Rusdiarso, B., Sakti, S. C. W., \& Tanaka, S. (2014). Coating of magnetite with mercapto modified rice hull ash silica in a one-pot process. SpringerPlus, 3(1), 515.

[15] Nuryono, N., \& Narsito, N. (2010). Effect Of Acid Concentration On Characters Of Silica Gel Synthesized From Sodium Silicate. Indonesian Journal of Chemistry, 5(1), 23-30.

[16] Rusdiarso, B., Kunarti, E. S., \& Hamdiani, S. (2008). Synthesis of Mesoporous Methyl-Silica Hybrid for Adsorption of Alizarin Red-s. Indonesian Journal of Chemistry, 8(2), 193-199.

[17] Asnawati, D., Sudarma, I. M., Yuanita, E., Arlina, B. F., Hamdiani, S., \& Kamali, S. R. (2015). Methylation of Eugenol Using Dimethyl Carbonate and Bentonite as Catalyst. Indonesian Journal of Chemistry, 15(3), 256-262. 